\title{
Verzuimmeting via zelfrapportage en registratie: verschillen tussen de Nationale Enquête Arbeidsomstandigheden en de Nationale Verzuim Statistiek
}

\author{
Ernest M.M. de Vroome, ${ }^{1}$ Lando L.J. Koppes, ${ }^{1}$ Peter G.W. Smulders, ${ }^{1}$ Seth N.J. van den Bossche ${ }^{1}$
}

\begin{abstract}
In onderzoek naar (arbeidsgerelateerde) risicofactoren voor ziekteverzuim wordt veelal volstaan met zelfgerapporteerd verzuim als uitkomstvariabele. Als zowel risicofactoren als uitkomstmaat zijn gebaseerd op vragenlijstgegevens kan dit echter leiden tot monomethod bias. In het hier gepresenteerde onderzoek wordt verzuim gemeten met zowel zelfrapportage- (de Nationale Enquête Arbeidsomstandigheden, NEA), als met registratiemethoden (de Nationale Verzuim Statistiek, NVS), onder dezelfde personen $(N=9.893)$. In absolute zin blijkt het gemiddelde zelfgerapporteerde verzuim significant hoger te liggen dan het geregistreerde verzuim $(4,6 v s 3,8 \%)$, maar beide bronnen blijken onderling wel consistent te zijn (relatief hoog verzuim volgens de ene bron is tevens relatief hoog verzuim volgens de andere bron). Op uitzonderingen na leiden analyses op basis van het zelfgerapporteerde verzuim en het geregistreerde verzuim tot dezelfde conclusies ten aanzien van verzuimrisicofactoren en de vraag welke subgroepen een relatief hoog verzuimpercentage hebben. Monomethod bias lijkt daarmee geen groot probleem te zijn bij het analyseren van ziekteverzuim en (arbeidsgerelateerde) risicofactoren van ziekteverzuim, als beide zijn gemeten in vragenlijstonderzoek. Zelfgerapporteerd ziekteverzuim in grootschalig steekproefonderzoek lijkt daarmee een betrouwbaar alternatief te vormen voor geregistreerd ziekteverzuim.
\end{abstract}

Trefwoorden: ziekteverzuim, monitoring, zelfrapportage, registratie, monomethod bias

\section{IN LEIDING}

In de periode 2002-2005 publiceerde het CBS jaarlijks de Nationale Verzuim Statistiek (NVS). ${ }^{1}$ De NVS gaf een uniform verzuimpercentage van de Nederlandse werknemers en werd onder meer via CBS-Statline algemeen toegankelijk gemaakt. In dit verzuimcijfer waren in 2005 circa vier miljoen Nederlandse werknemers betrokken. ${ }^{2}$ De NVS had echter te kampen met het probleem dat de registratie van verzuim verslechterde. Dat kwam onder meer door de liberalisering van de arbodienstverlening sinds 2004. De Wet Verplichting Loondoorbetaling verplicht werkgevers in Nederland sinds 2004 om het loon van hun verzuimende werknemers gedurende twee jaar door te betalen. Deze verplichting heeft er toe geleid dat veel werkgevers het verzuim van hun werknemers minder goed bijhouden en minder gemotiveerd zijn om hun verzuimgegevens centraal te melden. Onder meer door deze aanleveringsproblemen is de NVS na 2005 gestopt.

${ }^{1}$ TNO Kwaliteit van Leven | Arbeid, Hoofddorp
Aan de andere kant is door TNO, in samenwerking met het CBS en het ministerie van SZW, in 2003 de jaarlijkse Nationale Enquête Arbeidsomstandigheden (NEA) gestart. Dit is een grootschalige enquête die wordt afgenomen bij een door het CBS uit het Banenbestand getrokken representatieve steekproef uit alle werknemers in Nederland. De netto steekproef bestaat jaarlijks uit circa 25.000 werknemers. In deze enquête wordt onder meer naar het ziekteverzuim gevraagd. De vraag is nu of de zelfgerapporteerde verzuiminformatie uit de NEA de verzuimregistratiegegevens op basis van de NVS kan vervangen.

Eerder onderzoek laat zien dat zelfgerapporteerd verzuim gewoonlijk lager is dan geregistreerd verzuim. De Wit e.a. ${ }^{3}$ concluderen op basis van hun onderzoek bij enkele Vlaamse ziekenhuizen een onderrapportage van 10 tot $12 \%$ in het aantal verzuimde dagen. Van Poppel e.a. ${ }^{4}$ baseren zich op een kleine steekproef en concluderen dat de duur van de verzuimgevallen in een bedrijfsregistratiesysteem gemiddeld enkele dagen langer is dan 
in de vragenlijsten. Voss e.a. ${ }^{5}$ baseren zich op gegevens van bijna 5.000 werknemers van diverse

Zweedse gemeenten. Het zelfgerapporteerde aantal verzuimdagen over dezelfde 12 maanden is in hun onderzoek beduidend lager dan het geregistreerde aantal. Voss e.a. ${ }^{5}$ concluderen echter dat er, ondanks het absolute niveauverschil, een grote consistentie is tussen beide methoden: hoogverzuimers volgens de ene methode zijn dat ook volgens de andere methode. Ferrie e.a. ${ }^{6}$ vergeleken het verzuim volgens zelfrapportage van 8.000 Britse ambtenaren met dat wat hun werkgever registreerde. De discrepantie tussen beide methoden over een periode van 12 maanden bleek in dit onderzoek gering. Net als De Wit e.a. ${ }^{3}$ concludeert ook Johns ${ }^{7}$ dat de onderrapportage toeneemt met de lengte van de terugvraagperiode - hoe langer die is, hoe groter de 'recall bias'. Anderzijds concludeert Johns ${ }^{7}$ op basis van diverse studies, evenals Voss e.a., ${ }^{5}$ dat er een aanzienlijke consistentie bestaat tussen de ene en de andere methode, en benadrukt dat administratieve registraties minder perfect zijn dan vaak wordt verondersteld, met name als het gaat om kortdurende gevallen.

In het hier gerapporteerde onderzoek hebben we het verzuim bij dezelfde personen en in dezelfde periode zowel gemeten met behulp van een registratiesysteem (NVS), als met behulp van zelfrapportage in een enquêteonderzoek (NEA). Een belangrijk verschil met de in de literatuur vermelde onderzoeken ${ }^{3-7}$ is dat het hier om zeer grote en nationale bestanden gaat, en waarin ook meerdere bedrijfssectoren zijn betrokken. Door de registratiegegevens van de NVS op persoonsniveau te koppelen aan de zelfrapportagegegevens uit de NEA kan worden bekeken wat de bruikbaarheid is van beide verzuimstatistieken. Vergelijking vindt op twee verschillende manieren plaats:

- Direct, beide verzuimcijfers zijn bij dezelfde persoon beschikbaar en worden vergeleken op onder- en overrapportage, consistentie en absolute overeenkomst, en: - Indirect, komen er in onderzoek naar de determinanten van ziekteverzuim globaal dezelfde (arbeidsgerelateerde) risicofactoren naar voren als het gaat om zelfgerapporteerd dan wel geregistreerd verzuim.

In de nationale- en internationale onderzoeksliteratuur zijn veel demografische, gezondheids- en arbeidsgerelateerde risicofactoren aangewezen die samenhangen met ziekteverzuim. ${ }^{8-18}$ Mogelijk zijn de risicofactoren die tot nu toe in de internationale literatuur zijn gerapporteerd echter andere dan die in Nederland een grote rol spelen en/of andere dan die momenteel van belang zijn. Inzicht in de actuele (arbeidsgerelateerde) risicofactoren van verzuim is van belang voor de preventie van vermijdbaar verzuim. De kritiek op dergelijke studies is echter vaak die van monomethod bias: associaties kunnen ten onrechte worden gevonden doordat oorzaak en gevolg met dezelfde methode worden gemeten, en daarmee kunstmatige samenhang ontstaat. ${ }^{19}$ Als beide aspecten vrijwel gelijktijdig via vragenlijstonderzoek worden gemeten, kunnen respondenten hun antwoorden op vragen over verzuimoorzaken bewust of onbewust in overeenstemming brengen met hun antwoorden over hun verzuim. In deze studie onderzoeken we dit aspect door na te gaan of de associaties tussen (arbeidsgerelateerde) risicofactoren en verzuim dezelfde zijn, als zelfgerapporteerd verzuim wordt vervangen door geregistreerd verzuim.

\section{METHODE}

\section{NEA-2005}

De NEA is een groot Nederlands periodiek enquêteonderzoek onder een representatieve steekproef van $\mathrm{Ne}-$ derlandse werknemers (exclusief zelfstandigen). ${ }^{20-21} \mathrm{De}$ eerste NEA-meting vond in 2003 plaats; in novemberdecember 2005 is in samenwerking tussen het CBS en TNO de NEA-meting verricht die in deze publicatie wordt gebruikt, en inmiddels is dit onderzoek ook in 2006, 2007, en 2008 uitgevoerd. Ten behoeve van dit onderzoek wordt door het CBS telkens een steekproef van 80.000 werknemers uit het zogenoemde Banenbestand getrokken. Dit Banenbestand bevat gegevens over alle banen van werknemers in Nederland die verzekerd zijn voor de werknemersverzekeringen, en voor wie loonbelasting is verschuldigd. Circa 23.400 werknemers deden uiteindelijk aan de NEA-2005 mee, waarbij het responspercentage na correctie is vastgesteld op 33\%. De gegevens zijn verzameld door verzending van papieren vragenlijsten waarop zowel schriftelijk als via internet kon worden gerespondeerd.

\section{Verzuim volgens NEA-zelfrapportage}

Gevraagd is of men in de afgelopen twaalf maanden had verzuimd, en zo ja, om hoeveel werkdagen dat ging (exclusief zwangerschapsverlof). Tevens is gevraagd hoeveel dagen per week zij volgens contract werkten. Het reguliere aantal werkbare dagen per jaar in Nederland (215; CBS Webmagazine, 28 augustus 2006) werd per respon- 
Tabel 1 Percentage NEA-2005-respondenten bij wie een NVS-2005record kon worden gekoppeld.

\begin{tabular}{ll}
\hline & $\begin{array}{l}\text { Dekkings- } \\
\text { percentage }\end{array}$ \\
\hline Totaal $(N=15.368)$ & 67 \\
Geslacht & \\
Vrouw $(N=6.138)$ & $65 \mathbf{\nabla}$ \\
Man $(N=9.230)$ & $68 \mathbf{\Delta}$ \\
Leeftijd & \\
$15-24(N=2.566)$ & 66 \\
$25-34(N=3.285)$ & 66 \\
$35-44(N=4.030)$ & 68 \\
$45-54(N=3.679)$ & 68 \\
$55-64(N=1.808)$ & $64 \mathbf{~}$ \\
Sector & \\
Delfstoffen, industrie en energie $(N=2.805)$ & $68 \mathbf{\Delta}$ \\
Bouwnijverheid $(N=1.089)$ & 69 \\
Handel $(N=3.509)$ & 65 \\
Horeca $(N=603)$ & $76 \mathbf{\Delta}$ \\
Vervoer en communicatie $(N=1.250)$ & $71 \mathbf{\Delta}$ \\
Zakelijke dienstverlening $(N=3.223)$ & $65 \mathbf{\nabla}$ \\
Overheid $(N=2.084)$ & $62 \mathbf{\nabla}$ \\
Cultuur $(N=805)$ & $70 \mathbf{\Delta}$ \\
\hline
\end{tabular}

$\boldsymbol{\Delta} / \boldsymbol{\nabla}: \mathrm{p}<0,05$ voor significant hoge/lage percentages ten opzichte van de overige respondenten.

dent gecorrigeerd voor het aantal dagen dat hij of zij per week werkte. Op basis van deze verzuim- en deeltijdgegevens is voor iedere persoon zijn of haar verzuimpercentage berekend. Ook is het percentage werknemers bepaald dat in het rapportagejaar ten minste eenmaal heeft verzuimd.

\section{Verzuim volgens NVS registratie}

Het geregistreerde verzuim is gemeten met de NVS en betreft in deze analyses alleen het kalenderjaar 2005. De cijfers omtrent ziektegevallen in de NVS waren afkomstig van vier van de zes grote Nederlandse arbodiensten, aangevuld met 'vangnetgevallen' voor de Ziektewet van het Uitvoeringsinstituut Werknemersverzekeringen (UWV). De NVS gaf daarmee het verzuim weer van 60 tot $75 \%$ van alle werknemers in Nederland (exclusief zelfstandigen). Deze gegevens vormden de 'teller' van het NVS-verzuimpercentage. De 'noemer' van dat percentage was gebaseerd op gegevens over dienstverbanden, afkomstig uit de registratie 'Verzekerde Personen en Dienstverbanden' (VPD) van het UWV.

In de sectoren landbouw, visserij, financiële instellingen, onderwijs, en gezondheids- en welzijnszorg waren onvoldoende gegevens geleverd. Zij blijven hier verder buiten beschouwing. ${ }^{1-2}$ Deze sectoren zijn ook uit het VPD-'noemerbestand' verwijderd. In 2005 bevatte de NVS na deze selectie 3.932.768 personen. Eventuele ziektedagen bij meerdere dienstverbanden zijn bij elkaar opgeteld, en gedeeld door het totale aantal gewerkte uren. Zwangerschapsverlof is evenals in de NEA niet meegerekend als verzuim.

De respondenten in het NEA-onderzoek en de geregistreerde personen in de NVS zijn door het Centrum voor Beleidsstatistiek van het CBS voorzien van hun versleutelde Burger Service Nummer (BSN). Vervolgens zijn beide bestanden volkomen vertrouwelijk toegankelijk gemaakt voor het huidige onderzoek, en zijn beide bestanden met behulp van het versleutelde BSN op persoonsniveau gekoppeld. ${ }^{22-23}$

\section{Verzuim naar (arbeidsgerelateerde) risicofactoren}

Gegevens omtrent (arbeidsgerelateerde) risicofactoren zijn in november-december 2005 met de NEA gemeten. Hieronder vallen een aantal demografische factoren en algemene risicofactoren (bijvoorbeeld de gezondheidstoestand), en een aantal uit de literatuur bekende arbeidsgerelateerde risicofactoren voor verzuim. De factoren werkdruk, emotioneel zwaar werk, fysieke belasting, en gebrek aan autonomie (zelfstandigheid in het werk) zijn elk met meerdere items gemeten, die samen telkens een betrouwbare schaal vormen. ${ }^{20}$

\section{Analyses}

De sectoren die niet in de NVS zijn opgenomen (landbouw, visserij, financiële instellingen, onderwijs, en de gezondheids- en welzijnszorg), zijn eveneens bij voorbaat uit het NEA-bestand verwijderd. Na deze selectie konden er potentieel 15.368 NEA-respondenten worden gekoppeld aan hun NVS-gegevens. Gerapporteerd wordt hoeveel procent van deze NEA-respondenten kon worden teruggevonden in de registratie (NVS). Verschillen in dit dekkingspercentage naar geslacht, leeftijd en sector zijn getoetst met de Pearson $\mathrm{Chi}^{2}$ en bijbehorende Adjusted Standardized Residuals. ${ }^{24}$

Bij de directe vergelijking tussen de NEA- en de NVSverzuimcijfers kijken we eerst naar enkele indices die consistentie uitdrukken. Zowel de 'gewone' Pearson correlatie als de Spearman rangorde correlatie laten zien of relatief hoog volgens de NEA ook relatief hoog is volgens de NVS. Daarnaast kijken we naar een index die naast consistentie ook de absolute overeenkomst verdisconteert, de Intraclass Correlation Coefficient $\left(\right.$ ICC $\left._{\text {agreement }}\right){ }^{25}$ Tevens wordt het absolute niveau van verzuim volgens beide bronnen statistisch vergeleken (McNemar toets voor 'niet/wel verzuim', gepaarde $t$-test voor het verzuimpercentage).

Vervolgens rapporteren we van beide bronnen het verzuimpercentage en het percentage werknemers dat minimaal eenmaal heeft verzuimd; telkens uitgesplitst naar demografische en (arbeidsgerelateerde) risicofactoren. Bekeken wordt of het verzuim in bepaalde subgroepen relatief hoog is. $\mathrm{Bij}$ de continue variabele 'verzuimpercentage' is dat met ANOVA getoetst, waarbij als contrast is gehanteerd: groep versus alle andere groepen, het zogenaamde deviatiecontrast. Bij de dichotome variabele 'ten minste eenmaal verzuimd' is dat getoetst met de $\mathrm{Chi}^{2}$-toets, in combinatie met Adjusted Standardized Residuals. ${ }^{24}$ Deze laatste statistiek komt voor dichotomieën ook neer op het deviatiecontrast, en laat zien in welke groep het verzuim relatief laag dan wel hoog is ten opzichte van alle andere groepen gezamenlijk. 


\section{RESULTATEN}

\section{Dekkingsgraad}

Van de 15.368 potentieel beschikbare NEA-2005 respondenten (exclusief landbouw, visserij, financiële instellingen, onderwijs, en de gezondheids- en welzijnszorg), konden er 10.246 (67\%) succesvol worden gekoppeld aan een overeenkomstig NVS-record. In Tabel 1 wordt weergegeven in welke mate dit percentage samenhangt met geslacht, leeftijd, en sector. De verschillen tussen de subgroepen in hun dekkingspercentage zijn weliswaar significant, maar klein. Verhoudingsgewijs werd bij vrouwen wat minder vaak het overeenkomstige NVS-record teruggevonden, eveneens relatief minder vaak bij respondenten ouder dan 55 jaar, en ook minder vaak in de zakelijke dienstverlening en bij de overheid.

\section{Consistentie en overeenkomst tussen verschillende databronnen}

Vervolgens vergelijken we in de subgroep die succesvol is gekoppeld eerst hun zelfgerapporteerde verzuim (NEA, ten minste eenmaal in het verslagjaar) met hun geregistreerde verzuim (NVS, eveneens ten minste eenmaal in het verslagjaar, Tabel 2). Van de respondenten met ten minste één NVS-verzuimregistratie, had 79\% de NEA verzuimvraag met ' $J a$ ' beantwoord. De sensitiviteit van de NEA ten opzichte van de NVS is daarmee $79 \%$. Van degenen zonder verzuimregistratie had $30 \%$ toch een 'Ja'-antwoord op de NEA verzuimvraag. De specificiteit van de NEA ten opzichte van de NVS is daarmee $70 \%$. Hoewel zelfgerapporteerd en geregistreerd verzuim onderling consistent zijn (Kappa =0,49; Odds Ratio = 9,1), is er tegelijkertijd een substantieel absoluut- of niveauverschil. De zelfrapportage (NEA) constateert alles bij elkaar significant meer personen die ten minste eenmaal hebben verzuimd (53\%) dan de registratie (NVS, 47\%; McNemar toets, $p<0,001$ ).

Ook het zelfgerapporteerde verzuimpercentage en het geregistreerde verzuimpercentage zijn onderling consistent, de Pearson correlatie tussen beide is 0,65 , en Spearman's rangordecorrelatie is 0,59 . Deze twee coëfficiënten laten zien dat de relatieve positie van het verzuimpercentage van een persoon ten opzichte van de overige personen consistent is (relatief hoog in NVS is relatief hoog in NEA). In de Intraclass Correlation Coefficient (ICC) wordt niet alleen de consistentie, maar ook de absolute overeenkomst tussen beide indices verdisconteerd ${ }^{25}$ en deze is eveneens redelijk hoog (ICC $C_{\text {agreement, }}$ single measure $=0,63)$. Het gemiddelde verzuimpercentage volgens zelfrapportage (NEA, 4,6\%) is alles bij elkaar echter significant hoger dan het gemiddelde verzuimpercentage volgens registratie (NVS, $3,8 \%$, gepaarde $t$-test, $t(8.497)=7,7, p<0,001)$.

\section{Overeenkomst NEA en NVS in het detecteren van (arbeidsgerelateerde) risicofactoren van verzuim}

Tabel 3 laat het verzuimpercentage zien en het percentage werknemers dat ten minste eenmaal heeft verzuimd, zowel volgens de NEA als de NVS. Dit betreft alleen de 8.498 werknemers die succesvol konden worden gekoppeld en geen missende waarden hadden op de onderzochte demografische en (arbeidsgerelateerde) risicofactoren. Het gemiddelde verzuimpercentage in deze groep was in de NEA 4,6\% en in de NVS 3,8\%. Het percentage dat ten minste eenmaal heeft verzuimd in de verslagperiode is in deze groep 54\% volgens de NEA en $47 \%$ volgens de NVS. Deze percentages worden in Tabel 3 vervolgens uitgesplitst naar een groot aantal subgroepen gebaseerd op demografische en (arbeidsgerelateerde) risicofactoren.

De verschillen tussen deze subgroepen op zelfgerapporteerd verzuim (NEA) zijn grotendeels gelijk aan, en wijzen in dezelfde richting, als de verschillen tussen die subgroepen op geregistreerd verzuim (NVS). Met andere woorden, subgroepen die een relatief hoog verzuim hebben volgens de NEA hebben tevens een relatief hoog verzuim volgens de NVS. Dat geldt zowel voor het verzuimpercentage als het percentage werknemers dat ten minste eenmaal heeft verzuimd.

Zowel met behulp van de NEA als met behulp van de NVS zien we dat ouderen en laag opgeleiden een hoger verzuimpercentage vertonen dan jongeren respectievelijk hoog opgeleiden. Dit is ook in veel eerder onderzoek vastgesteld. Minimaal eenmaal verzuim is in de oudste groep en onder de laag opgeleiden juist lager; de verzuimgevallen duren in deze groepen met andere woorden gemiddeld wat langer. Gehuwden en degenen met meer dan 3 uur huishoudelijke- en zorgtaken verzuimen volgens elke methode en index relatief meer. Verder is zowel aan de NEA- als aan de NVS-verzuimcijfers te zien dat werknemers met een minder goede gezondheidstoestand, een chronische aandoening en/of een arbeidsongeschiktheidsuitkering beduidend meer verzuimen dan degenen met een goede of uitstekende gezondheid. Zowel in de NEA als de NVS zien we dat werknemers in vaste dienst meer verzuim vertonen dan degenen met een flexibele

Tabel 2 Percentage respondenten dat ten minste eenmaal heeft verzuimd in het afgelopen jaar volgens zelfrapportage (NEA-2005), naar ten minste één verzuimregistratie (NVS-2005) (aantal respondenten).

\begin{tabular}{|c|c|c|c|c|}
\hline \multirow[b]{2}{*}{ Verzuim volgens zelfrapportage (NEA-2005) } & & \multicolumn{2}{|c|}{ Verzuim volgens registratie (NVS-2005) } & Totaal \\
\hline & $\begin{array}{l}\text { Nee } \\
\text { Ja } \\
\text { Totaal }\end{array}$ & $\begin{array}{l}70(3.703) \\
30(1.560) \\
53(\mathbf{5 . 2 6 3 )}\end{array}$ & $\begin{array}{l}21(954) \\
79(3.676) \\
47(4.630)\end{array}$ & $\begin{array}{l}47(4.657) \\
53(5.236) \\
100(9.893)\end{array}$ \\
\hline
\end{tabular}

- Kappa = 0,49;

- Odds Ratio = 9,1;

- Sensitiviteit NEA ten opzichte van NVS = 79\%;

- Specificiteit NEA ten opzichte van NVS = 70\%;

- Verzuim in de NEA (53\%) is significant hoger dan in de NVS (47\%): McNemar toets, p < 0,001. 
Tabel 3 Verzuim volgens zelfrapportage (NEA-2005) en volgens registratie (NVS-2005), naar demografische en (arbeidsgerelateerde) risicofactoren $(N=8.498$, alleen degenen met gegevens op alle onderstaande variabelen).

\begin{tabular}{|c|c|c|c|c|}
\hline $\begin{array}{l}\text { Demografische en (arbeidsgerelateerde) } \\
\text { risicofactoren (percentage respondenten) }\end{array}$ & $\begin{array}{l}\text { Verzuimpercentage } \\
\text { Zelfrapportage } \\
\text { (NEA) (\%) }\end{array}$ & $\begin{array}{l}\text { Geregistreerd } \\
\text { (NVS) (\%) }\end{array}$ & $\begin{array}{l}\text { Percentage ten } \\
\text { Zelfrapportage } \\
\text { (NEA) (\%) }\end{array}$ & $\begin{array}{l}\text { eenmaal verzuimd } \\
\text { Geregistreerd } \\
\text { (NVS) (\%) }\end{array}$ \\
\hline \multicolumn{5}{|l|}{ Geslacht } \\
\hline Man (61) & $4,1 \nabla$ & 3,7 n.s. & $52 \nabla$ & 47 n.s. \\
\hline \multicolumn{5}{|l|}{ Leeftijd } \\
\hline$<25(17)$ & $2,8 \nabla$ & $1,6 \nabla$ & $49 \nabla$ & $28 \nabla$ \\
\hline $25-34(22)$ & 4,3 & 3,6 & $60 \Delta$ & $50 \Delta$ \\
\hline $35-44(28)$ & 4,6 & 4,1 & $57 \boldsymbol{\Delta}$ & $52 \Delta$ \\
\hline $45-54(24)$ & $5,6 \Delta$ & $4,5 \Delta$ & $51 \nabla$ & $51 \Delta$ \\
\hline $55+(10)$ & $6,4 \Delta$ & $5,2 \Delta$ & $48 \nabla$ & 50 \\
\hline \multicolumn{5}{|l|}{ Opleiding } \\
\hline $\mathrm{T} / \mathrm{m}$ middelbare school (38) & $5,6 \triangle$ & $4,5 \Delta$ & $52 \nabla$ & $45 \nabla$ \\
\hline MBO (34) & 4,8 & 4,0 & 55 & 47 \\
\hline HBO-WO (29) & $3,2 \nabla$ & $2,6 \nabla$ & 55 & $50 \Delta$ \\
\hline \multicolumn{5}{|l|}{ Herkomst } \\
\hline Autochtoon (88) & 4,6 n.s. & 3,8 n.s. & 54 n.s. & 47 n.s. \\
\hline Allochtoon (12) & 5,0 & 4,1 & 57 & 49 \\
\hline \multicolumn{5}{|l|}{ Leefsituatie } \\
\hline Gehuwd (71) & $4,9 \Delta$ & $4,2 \Delta$ & $55 \Delta$ & $51 \Delta$ \\
\hline Andere leefsituatie (29) & $4,0 \nabla$ & $2,9 \nabla$ & $52 \nabla$ & $38 \nabla$ \\
\hline \multicolumn{5}{|l|}{ Huishoudelijke- en zorgtaken } \\
\hline$<3$ uur per dag (68) & $4,1 \nabla$ & $3,4 \nabla$ & $53 \nabla$ & $46 \nabla$ \\
\hline $3+$ uur per dag (32) & $5,8 \boldsymbol{\Delta}$ & $4,6 \boldsymbol{\Delta}$ & $56 \Delta$ & $50 \Delta$ \\
\hline \multicolumn{5}{|l|}{ Algemene gezondheid } \\
\hline Matig/slecht (9) & $15,1 \Delta$ & $11,7 \boldsymbol{\Delta}$ & $77 \boldsymbol{\Delta}$ & $65 \Delta$ \\
\hline Goed (53) & $4,4 \mathbf{\nabla}$ & 3,6 & $57 \boldsymbol{\Delta}$ & $50 \Delta$ \\
\hline Zeer goed/uitstekend (37) & $2,4 \nabla$ & $2,0 \nabla$ & $43 \nabla$ & $39 \nabla$ \\
\hline \multicolumn{5}{|l|}{ Chronische aandoening } \\
\hline Nee $(67)$ & $3,1 \nabla$ & $2,5 \nabla$ & $49 \nabla$ & $43 \nabla$ \\
\hline Ja (33) & $7,8 \Delta$ & $6,4 \Delta$ & $63 \Delta$ & $55 \Delta$ \\
\hline \multicolumn{5}{|l|}{ Arbeidsongeschiktheidsuitkering } \\
\hline Nee (98) & $4,5 \nabla$ & $3,6 \nabla$ & 54 n.s. & $47 \boldsymbol{\nabla}$ \\
\hline $\mathrm{Ja}(2)$ & $11,0 \Delta$ & $10,3 \boldsymbol{\Delta}$ & 58 & $56 \Delta$ \\
\hline \multicolumn{5}{|l|}{ Bedrijfssector } \\
\hline Delfstoffen, industrie en energie (18) & 4,9 & $4,5 \Delta$ & 53 & $54 \boldsymbol{\Delta}$ \\
\hline Bouwnijverheid (7) & 5,0 & $5,4 \Delta$ & 51 & 47 \\
\hline Handel (22) & 4,6 & 3,6 & $51 \nabla$ & $36 \nabla$ \\
\hline Horeca (4) & 4,1 & $1,6 \nabla$ & $44 \nabla$ & $25 \nabla$ \\
\hline Vervoer en communicatie (9) & 4,9 & 4,3 & $49 \nabla$ & 50 \\
\hline Zakelijke dienstverlening (21) & $4,0 \nabla$ & $2,9 \nabla$ & $57 \boldsymbol{\Delta}$ & 47 \\
\hline Overheid (13) & 5,2 & 4,3 & $64 \Delta$ & $65 \Delta$ \\
\hline Cultuur (5) & 4,5 & 3,6 & 55 & 44 \\
\hline Type dienstverband & & & ענד & \\
\hline Flexibel (19) & $3,4 \nabla$ & $2,0 \nabla$ & $47 \nabla$ & $31 \nabla$ \\
\hline Vast (81) & $4,9 \Delta$ & $4,2 \Delta$ & $56 \Delta$ & $51 \Delta$ \\
\hline Contracturen & & & & \\
\hline$<26(24)$ & 4,7 & $3,4 \nabla$ & $49 \nabla$ & $34 \nabla$ \\
\hline $26-35(13)$ & $5,5 \Delta$ & 3,6 & $61 \Delta$ & $54 \boldsymbol{\Delta}$ \\
\hline $36+(63)$ & 4,5 & $4,0 \Delta$ & 54 & $51 \Delta$ \\
\hline Overwerk & & & & \\
\hline Nooit (27) & $6,1 \boldsymbol{\Delta}$ & $4,9 \boldsymbol{\Delta}$ & 55 & 48 \\
\hline Incidenteel (46) & 4,4 & 3,6 & $56 \Delta$ & $49 \boldsymbol{\Delta}$ \\
\hline Structureel (28) & $3,7 \mathrm{~V}$ & $3,1 \nabla$ & $49 \nabla$ & $44 \nabla$ \\
\hline 's Avonds/s nachts werken & & & & \\
\hline Nee of soms $(78)$ & 4,7 n.s. & 3,9 n.s. & 54 n.s. & $49 \boldsymbol{\Delta}$ \\
\hline Ja, regelmatig (22) & 4,6 & 3,4 & 53 & $42 \nabla$ \\
\hline Bedrijfsgrootte & & & & \\
\hline <100 personen (6o) & 4,6 n.s. & $3,4 \nabla$ & $52 \nabla$ & $41 \nabla$ \\
\hline $100+$ personen (40) & 4,8 & $4,4 \boldsymbol{\Delta}$ & $57 \boldsymbol{\Delta}$ & $57 \boldsymbol{\Delta}$ \\
\hline Werkdruk & & & & \\
\hline Laag (33) & $4,1 \nabla$ & $3,2 \nabla$ & $50 \nabla$ & $41 \nabla$ \\
\hline Middelmatig (36) & $4,2 \nabla$ & 3,6 & 55 & 47 \\
\hline Hoog (31) & $5,7 \Delta$ & $4,6 \boldsymbol{\Delta}$ & $57 \boldsymbol{\Delta}$ & $54 \boldsymbol{\Delta}$ \\
\hline Emotioneel zwaar werk & & & & \\
\hline Niet (47) & $4,1 \nabla$ & $3,3 \nabla$ & $52 \nabla$ & $44 \nabla$ \\
\hline Middelmatig (32) & 4,5 & 3,9 & 55 & 48 \\
\hline Zwaar (21) & $6,1 \Delta$ & $4,8 \boldsymbol{\Delta}$ & $57 \boldsymbol{\Delta}$ & $53 \boldsymbol{\Delta}$ \\
\hline
\end{tabular}




\begin{tabular}{|c|c|c|c|c|}
\hline $\begin{array}{l}\text { Demografische en (arbeidsgerelateerde) } \\
\text { risicofactoren (percentage respondenten) }\end{array}$ & $\begin{array}{l}\text { Verzuimpercentage } \\
\text { Zelfrapportage } \\
\text { (NEA) (\%) }\end{array}$ & $\begin{array}{l}\text { Geregistreerd } \\
\text { (NVS) (\%) }\end{array}$ & $\begin{array}{l}\text { Percentage ten } \\
\text { Zelfrapportage } \\
\text { (NEA) (\%) }\end{array}$ & $\begin{array}{l}\text { Genmaal verzuimd } \\
\text { Geregistreerd } \\
\text { (NVS) (\%) }\end{array}$ \\
\hline \multicolumn{5}{|l|}{ Fysieke belasting } \\
\hline Niet (46) & $4,1 \nabla$ & $3,3 \nabla$ & $55 \Delta$ & $51 \boldsymbol{\Delta}$ \\
\hline Middelmatig (28) & 4,6 & 3,7 & $52 \nabla$ & $42 \nabla$ \\
\hline Zwaar (26) & $5,6 \wedge$ & $4,7 \Delta$ & 54 & 46 \\
\hline \multicolumn{5}{|l|}{ Gevaarlijk werk } \\
\hline Nee $(74)$ & $4,3 \mathbf{\nabla}$ & $3,4 \nabla$ & 53 n.s. & 47 n.s. \\
\hline Ja, soms/regelmatig (26) & $5,7 \Delta$ & $4,9 \boldsymbol{\Delta}$ & 55 & 49 \\
\hline \multicolumn{5}{|l|}{ Agressie/intimidatie collega's } \\
\hline Niet (92) & $4,2 \nabla$ & $3,5 \nabla$ & $53 \boldsymbol{\nabla}$ & $46 \nabla$ \\
\hline Wel (8) & $9,9 \boldsymbol{\Delta}$ & $7,3 \boldsymbol{\Delta}$ & $69 \Delta$ & $57 \boldsymbol{\Delta}$ \\
\hline \multicolumn{5}{|l|}{ Agressie/intimidatie klanten } \\
\hline Niet (91) & $4,5 \nabla$ & $3,7 \nabla$ & $53 \boldsymbol{\nabla}$ & 47 n.s. \\
\hline Wel (9) & $6,5 \Delta$ & $5,1 \wedge$ & $62 \Delta$ & 49 \\
\hline \multicolumn{5}{|l|}{ Tevredenheid arbeidsomstandigheden } \\
\hline (Zeer) tevreden (70) & $3,5 \nabla$ & $3,0 \nabla$ & $50 \nabla$ & $45 \nabla$ \\
\hline Ontevreden/neutraal (30) & $7,2 \Delta$ & $5,5 \Delta$ & $62 \Delta$ & $52 \Delta$ \\
\hline \multicolumn{5}{|l|}{ Autonomie } \\
\hline Laag (29) & $6,2 \Delta$ & $4,7 \boldsymbol{\Delta}$ & $56 \Delta$ & 46 n.s. \\
\hline Middelmatig (27) & 4,3 & 3,7 & 54 & 48 \\
\hline Hoog (44) & $3,9 \nabla$ & $3,3 \mathbf{v}$ & $52 \nabla$ & 48 \\
\hline
\end{tabular}

$\boldsymbol{\Delta} / \boldsymbol{\nabla}: \mathrm{p}<0,05$ voor significant hoge/lage percentages.

Noot: Significantiesymbolen hebben betrekking op verschillen tussen subgroepen in verticale richting (bijvoorbeeld het verschil in verzuim tussen mannen en vrouwen, verschil in verzuim naar leeftijd etc.).

aanstelling. Het verzuim is in beide methoden en indices lager bij de deeltijdwerkers die minder dan 26 uur per week werken dan bij degenen die meer dan 26 uur per week werken. Structureel overwerk is in alle gevallen geassocieerd met minder verzuim. Dat kan wijzen op ziek doorwerken vanwege hoge werkdruk, maar ook op dat men door een goede gezondheid zowel beter in staat is om over te werken als minder snel ziek wordt. Ten slotte zien we dat de arbeidsgerelateerde risicofactoren (werkdruk, emotioneel zwaar werk, fysieke belasting, gevaarlijk werk, agressie/intimidatie van collega's en/of klanten, gebrek aan autonomie) alle in de verwachte richting wijzen. Alleen bij 'agressie/intimidatie van klanten' en bij 'autonomie' is de NVS niet significant als het gaat om de index ten minste eenmaal verzuimd. Bij 'fysieke belasting' valt op dat degenen zonder fysieke belasting procentueel minder verzuimen, maar juist vaak ten minste eenmaal. Dat komt neer op relatief veel maar kortere ziektegevallen per persoon in de subgroep 'geen fysieke belasting', en relatief minder maar langere ziektegevallen in de subgroep 'middelmatige of zware fysieke belasting'. Ook de verschillen in relatie tot tevredenheid met de arbeidsomstandigheden zijn vergelijkbaar, of men nu zelfgerapporteerde of geregistreerde verzuimgegevens gebruikt.

Daarnaast valt op dat in beide methoden allochtonen en autochtonen niet van elkaar verschillen. In beide methoden wordt geen associatie gevonden tussen verzuim en 's avonds en/of 's nachts werken. Alleen in de NVSindex 'ten minste eenmaal verzuim', zien we dat's avonds en/of 's nachts werken is geassocieerd met minder verzuim (vergelijkbaar met het resultaat bij overwerk).

Opvallend is echter het verschil tussen de NEA en de NVS in de mate van verzuim naar sekse, sector en bedrijfsgrootte. De NEA geeft significant meer verzuim voor vrouwen dan voor mannen; de NVS geeft geen significant sekseverschil. De NEA-cijfers zijn wat dit sekseverschil in verzuim betreft in lijn met de verzuimliteratuur. Hoewel in beide methoden vooral de horeca en de zakelijke dienstverlening een relatief laag verzuimpercentage hebben, zien we in de NVS zowel bij de horeca als de zakelijke dienstverlening een buitengewoon laag absoluut verzuimpercentage. Wat bedrijfsgrootte betreft zien we dat de zelfrapportage geen verschil (bij verzuimpercentage) of slechts een klein verschil (bij ten minste eenmaal verzuim) constateert naar bedrijfsgrootte, waar de registratie een relatief groot verschil constateert.

\section{DISCUSSIE}

In tegenstelling tot eerder onderzoek ${ }^{3-7}$ vinden we in het beschikbare materiaal juist een hoger verzuimpercentage op basis van zelfrapportage dan op basis van registratie $(4,6$ vs $3,8 \%)$. Het verschil tussen deze twee verzuimpercentages komt gedeeltelijk doordat relatief veel werknemers zelf aangaven dat ze ten minste eenmaal hebben verzuimd, terwijl dat niet uit de registratie naar voren komt (54 vs 47\%).

De gesignaleerde verschillen in verzuim kunnen zijn ontstaan door onvolledige registratie in de NVS en/of door overrapportage in de NEA. De kritiek op zelfrapportage is over het algemeen echter dat het wordt beïnvloed door sociale wenselijkheid en recall bias, wat zou leiden tot onderrapportage. Mogelijk spelen sociale wenselijkheid en recall bias een rol bij de NEA verzuimcijfers, maar het zelfgerapporteerde verzuimcijfer komt daarmee in ieder geval niet onder dat van het geregistreerde verzuim.

Aan de andere kant kent ook 'objectieve' registratie systematische fouten, die samenhangen met de wijze van registreren. Zo zal de kwaliteit, controle en consistentie van een registratiesysteem binnen één bedrijf (bijvoorbeeld Van Poppel e.a. ${ }^{4}$ ) in principe beter zijn dan bij een registratiesysteem gebaseerd op data die worden aangeleverd door vele bedrijven en/of arbodiensten, zoals in het geval van de NVS. Zo brengt het inschakelen van een (externe) arbodienst kosten met zich mee, en wordt mede daardoor soms pas na enkele weken gedaan. De conse- 
quentie daarvan is dat vooral verhoudingsgewijs kortdurend verzuim niet in alle gevallen in de NVS terecht zal komen. Mogelijk verklaart dat het verschil tussen het relatief lage geregistreerde verzuim in de NVS ten opzichte van het geregistreerde verzuim in de literatuur ${ }^{3-7}$ en ten opzichte van het zelfgerapporteerde verzuim (NEA). Hoewel de NVS zich niet beperkt tot één sector zoals we in de literatuur vaak zagen, ontbreken in de NVS de sectoren landbouw, visserij, financiële instellingen, onderwijs, en de gezondheids- en welzijnszorg. Hoewel we deze sectoren voor een éénduidige vergelijking ook uit de NEA hebben gehaald, zijn met de NEA de verzuimcijfers van alle sectoren te onderzoeken. Maar ook in de sectoren die wel in de NVS zitten, zal onderregistratie voorkomen. Zo bleek ook uit mededelingen van arbodiensten dat de ziekmeldingenregistratie per werkgever soms onvolledig is, en onder meer last heeft van administratieve vertraging ${ }^{2}$ en onderrapportage. Daarnaast heeft het CBS in het NVS databestand enkele controle- en correctiemethoden uitgevoerd die hetzij tot onderdekking dan wel tot een te laag verzuimcijfer aanleiding kunnen geven. Met name van belang daarbij is dat bedrijven groter dan twintig werknemers met een 'onwaarschijnlijk' laag verzuimpercentage in de NVS zijn aangewezen als uitbijters en zijn verwijderd. Tot slot kunnen verschillen ontstaan doordat de NVS-2005 over de periode januari-december 2005 gaat, terwijl de NEA de twaalf maanden betreft die voorafgaan aan het invulmoment (november-december 2005), en de verslagperiodes daarmee niet volledig identiek zijn.

Het verschil in verzuim tussen de NEA en de NVS blijkt sterk afhankelijk te zijn van de bedrijfssector. Het verzuimpercentage is in de bouw volgens beide bronnen vrijwel gelijk (NEA 5,0 vs NVS 5,4\%), maar met name in de horeca en de zakelijke dienstverlening ligt het verzuimpercentage ruim hoger in de NEA dan in de NVS $(4,1$ vs $1,6 \%$ respectievelijk 4,0 vs $2,9 \%)$. Deze cijfers lijken er op te wijzen dat het verzuim met name in de horeca en de zakelijke dienstverlening wordt ondergeregistreerd. Daarnaast valt op dat de discrepantie tussen de NEA en de NVS bij grote bedrijven beduidend kleiner is dan bij kleine bedrijven. Dat kan worden veroorzaakt doordat grote bedrijven hun verzuimregistratie beter op orde hebben dan kleine bedrijven. De registratie lijkt ook beter op orde te zijn bij werknemers met een vast dienstverband, dan bij werknemers met een flexibel dienstverband. Mogelijk is het voor werkgevers relatief belangrijker en/of eenvoudiger om ziekteverzuim bij een vast dienstverband te registreren dan bij een flexibel dienstverband.

Hiaten in de aanlevering van de geregistreerde verzuimgegevens vormen vermoedelijk een belangrijke factor in de verklaring van de verschillen tussen beide bronnen. Een persoon die abusievelijk niet in het verzuimbestand zit, maar wel in het 'Verzekerde Personen en Dienstverbanden'-bestand, wordt in de NVS abusievelijk als niet-verzuimer gecategoriseerd. De NVS is in dat opzicht wel specifiek (een niet-verzuimer wordt zelden als verzuimer aangemerkt), maar in mindere mate sensitief (niet alle verzuimers komen als verzuimer in de NVS terecht, bijvoorbeeld doordat de arbodienst niet of pas laat wordt ingeschakeld).

Op grond van het bovenstaande is onze conclusie dat het algemene verzuimpercentage op basis van registratie (NVS) effectief kan worden vervangen door het algemene verzuimpercentage op basis van grootschalig representatief onderzoek met zelfrapportage (NEA). Een bezwaar is echter dat het volume van de NEA (jaarlijks circa 25.000 werknemers), beduidend kleiner is dan dat van de NVS (circa vier miljoen werknemers), waarmee vooral gedetailleerde uitsplitsingen van verzuim naar bijvoorbeeld bedrijfstak op SBI 3-digit of nog gedetailleerder niveau, minder nauwkeurige cijfers met de NEA, dan met de NVS zal opleveren. Daarentegen komen een aantal sectoren van de arbeidsmarkt niet voor in de NVS, terwijl deze wel worden gedekt door de NEA.

Daarnaast blijken vrijwel dezelfde (arbeidsgerelateerde) risicofactoren naar voren te komen, als in de analyse het zelfgerapporteerde- dan wel het geregistreerde verzuim wordt gebruikt. Met andere woorden, er lijkt bij gebruik van zelfgerapporteerde verzuimgegevens in relatie tot eveneens zelfgerapporteerde verzuim-risicofactoren geen groot gevaar voor monomethod bias te ontstaan, hetgeen overeenkomt met de analyse van Spector. ${ }^{19}$ Daarmee kan ook ter identificatie van (arbeidsgerelateerde) risicofactoren worden geconcludeerd dat verzuimregistratiegegevens (NVS) effectief kunnen worden vervangen door verzuimgegevens op basis van zelfrapportage in grootschalig steekproefonderzoek (NEA).

\section{ABSTRACT}

Measuring absenteeism through self-report or registration: Differences between the Netherlands Working Conditions Survey and the National Absence Registry

Research to establish (work related) risk factors of sickness absence is usually restricted to self-reported measures of sickness absence. When risk factors and outcome measures are both collected with self-administered questionnaires, however, this may suffer from monomethod bias. In the current research, absence was measured both with self-report (Netherlands Working Conditions Survey), as with registered measures (National Absence Registry), among the same individuals $(\mathrm{N}=9.893)$. On average, it appeared that self-reported absence was significantly higher than registered absence $(4,6$ vs $3,8 \%)$, but both measures also appeared to be consistent (relatively high on absence according to one source was also relatively high according to the other source). Apart from some exceptions, analyses using self-reported absence or registered absence reached the same conclusions regarding risk factors for sickness absence and the question in which subgroups sickness absence is relatively high. Therefore, monomethod bias appears not to be a major problem when analyzing sickness absence and (work related) risk factors of sickness absence, when both are measured with self-administered questionnaires. Self-reported sickness absence in research based on large-scale probability samples therefore appears to be a reliable alternative to registered sickness absence.

Key words: absenteeism, monitoring, self-report, registration, monomethod bias 


\section{LITERATUUR}

1. Linden F van der, Rijk $A$ de. Ziekteverzuim naar leeftijd en geslacht, 2002-2005. Voorburg/Heerlen: CBS, 2008.

2. Boerdam A, Bloemendal C, Geertjes K. Eindrapport haalbaarheidsonderzoek naar arbeidsgerelateerd verzuim in de Nationale Verzuim Statistiek (NVS). Voorburg: CBS, 2006.

3. Wit $R$ de, Moens $G$, D'Hondt $M$. Een onderzoek naar de validiteit van zelfgerapporteerd ziekteverzuim. Arbeidsgezondheidszorg en Ergonomie 1998;35:165-8.

4. Poppel MNN van, Vet HCW de, Koes BW, Smid T, Bouter LM. Measuring sick leave: A comparison of self-reported data on sick leave and data from company records. Occup Med 2002; 52:485-90.

5. Voss M, Stark S, Alfredsson L, Vingård E, Josephson M. Comparisons of self-reported and register data on sickness absence among public employees in Sweden. Occup Environ Med 2007; 65:61-7.

6. Ferrie JE, Kivimäki M, Head J, Shipley MJ, Vahtera J, Marmot $M G$. A comparison of self-reported sickness absence with absences recorded in employers' registers: Evidence from the Whitehall II study. Occup Environ Med 2005;62:74-9.

7. Johns G. How often were you absent? A review of the use of self-reported absence data. J Appl Psychol 1994;79:574-91.

8. Muchinsky PM. Employee absenteeism: A review of the literature. J Vocat Behav 1977;10:316-37.

9. Brooke PP, Price JL. The determinants of employee absenteeism: An empirical test of a causal model. J Occup Psychol 1989;62:1-19.

10. Duijts SFA, Kant I, Swaen GMH, Brandt PA van den, Zeegers MPA. A meta-analysis of observational studies identifies predictors of sickness absence. J Clin Epidemiol 2007;60:1105-11.

11. Geurts S, Smulders PGW. Ziekteverzuim en arbeidsongeschiktheid. In: Schaufeli W, Bakker A, Jonge J de (red). De psychologie van arbeid en gezondheid. Houten: Bohn, Stafleu, Van Loghum, 2007.

12. Goodman PS, Atkin RS (eds). Absenteeism: New approaches to understanding, measuring, and managing employee absence. San Francisco/London: Jossey-Bass, 1984.

13. Harrison DA, Martocchio JJ. Time for absenteeism: A 20-year review of origins, offshoots, and outcomes. JOM 1998;24:30550.

14. Johns G. Contemporary research on absence from work: Correlates, causes and consequences. International Review of Industrial and Organizational Psychology 1997;12:115-74.
15. North FM, Syme SL, Feeney A, Shipley M, Marmot M. Psychosocial work environment and sickness absence among British civil servants: The Whitehall II Study. Am J Public Health 1996; 86:332-40.

16. Steers $R M$, Rhodes $S R$. Major influences on employee attendance: A process model. J Appl Psychol 1978;63:391-407.

17. Steers RM, Rhodes SR. Knowledge and speculation about absenteeism. In: Goodman PS, Atkin RS (eds). Absenteeism: New approaches to understanding, measuring, and managing employee absence. San Francisco/London: Jossey-Bass, 1984.

18. Vroome EMM de, Putten DJ van. Werkgebonden risicofactoren van ziekteverzuim en huisarts- en specialistenbezoek. Tijdschr Gezondheidswet 2003;81:127-34.

19. Spector PE. Method variance in organizational research: Truth or urban legend? Organizational Research Methods 2006;9; 221-32.

20. Bossche S, Hupkens C, Ree S de, Smulders P. Nationale Enquête Arbeidsomstandigheden 2005: Methodologie en globale resultaten. TNO Kwaliteit van Leven | Arbeid, 2006.

21. Smulders $P$. Werksituatie en ziekteverzuim. In: Jehoel-Gijsbers $G$ (red). Beter aan het werk: trendrapportage ziekteverzuim, arbeidsongeschiktheid en werkhervatting. Den Haag: Sociaal en Cultureel Planbureau, 2007.

22. Hupkens Ch, Frenken F, Rijk A de. Documentatierapport NEA 2005. Voorburg: CBS, 2007.

23. Lycklama à Nijeholt, G. Documentatierapport NVS 2005. Voorburg: CBS, 2007.

24. Haberman SJ. Analysis of qualitative data. New York: Academic Press, 1978.

25. Vet HCW de, Terwee CB, Knol DL, Bouter LM. When to use agreement versus reliability measures. J Clin Epidemiol 2006; 59:1033-9.

\section{CORRESPONDENTIEADRES}

Dr. Ernest M.M. de Vroome, TNO Kwaliteit van Leven | Arbeid, Posbus 718, 2130 AS Hoofddorp, 023 - 554 9478, Ernest.deVroome@TNO.nl.

\section{NoOT}

Dit artikel is tot stand gekomen in het kader van de aan TNO toegewezen overheidsfinanciering op het terrein van het ministerie van $S Z W$.

Voor publicatie aanvaard in november 2009. 